CATALLAXY

Volume 1 Issue 1 December 2016

e-ISSN 2544-090X

ऽwww.catallaxy.pl

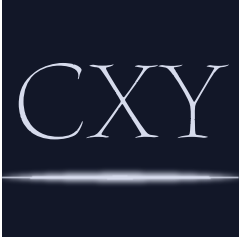

Oryginalny artykut naukowy

otrzymano: 05.12.2016 / zaakceptowano: 28.12.2016 / opublikowano online: 31.12 .2016

Zygadlewicz, M. (2016). Niemiecka polityka socjalna a kryzys migracyjny. Catallaxy, 1(1): 17-29. doi:10.24136/cxy. v1i1.2.

\title{
Niemiecka polityka socjalna a kryzys migracyjny
}

\author{
MACIEJ ZYGADLEWICZ \\ Wydział Nauk Ekonomicznych i Zarządzania, Uniwersytet Mikotaja Kopernika w Toruniu, ul. Gagarina 13a, \\ 87-100 Toruń, Polska \\ 口mzygadlewicz@gmail.com
}

\begin{abstract}
Abstrakt
Motywacja: Europejski kryzys migracyjny jest obecnie jednym z głównych problemów spoleczno-politycznych Europy. Wojny domowe, które rozpoczęły się w Syrii i Libii w 2011 roku, spowodowaly napływ imigrantów do Europy. Sytuacja ta nasilita się szczególnie w 2015 roku, zmuszając rządy państw europejskich do stworzenia warunków bytowych dla przybywających uchodźców. Docelowo bardzo duża część imigrantów dotarła aż do Republiki Federalnej Niemiec. Chęć ukazania jednej z przyczyn obrania akurat takiego kierunku migracji była głównym motywem wyboru tematu niniejszego artykułu.

Cel: Celem artykułu jest analiza związków między niemiecką polityką socjalną a powstaniem kryzysu migracyjnego w tym państwie. Badanie zostało przeprowadzone za pomocą oceny mierników ilościowych. Analizie zostały poddane dane Eurostat oraz Federalnego Urzędu Statystycznego Niemiec dotyczące wniosków o azyl oraz przepływów migracyjnych, jak również ustawy Deutscher Bundestagu dotyczące świadczeń socjalnych dla uchodźców.

Wyniki: Przeprowadzona analiza wykazała zależności między polityką socjalną prowadzoną przez rząd niemiecki a napływem imigrantów do tego państwa. Wysokie świadczenia socjalne dla uchodźców stanowily jeden z głównych czynników przyciągających migrantów.
\end{abstract}

Stowa kluczowe: kryzys migracyjny; polityka socjalna; Niemcy

JEL: JOO; EOO; FOO

1. Wprowadzenie

Obecne, masowe migracje w kierunku Europy, jakie można zaobserwować już od 2011 roku, określane są mianem kryzysu, który zgodnie $z$ definicją jest okresem "załamania, przesilenia i potencjalnego przełomu" (Encyklopedia PWN, 2017). Bezpośrednie przyczyny jego powstania były całkowicie niezależne od polityki jakiekolwiek państwa europejskiego, jednak skala jego natężenia w poszczególnych państwach była $w$ znaczącym stopniu przez nią zdeterminowana.
Niemcy zostały bardzo szybko obrane jako główny cel wędrówki uchodźców, co miało związek $z$ polityką pro imigracyjną, prowadzoną przez rząd niemiecki. Jednym $z$ jej najistotniejszych elementów były rozbudowane świadczenia socjalne $\mathrm{w}$ stosunku do azylantów oraz uchodźców. Analiza zaistniałej sytuacji pod tym kątem jest obecnie szczególnie ważna, gdyż kryzys migracyjny cały czas trwa i jest jednym $z$ głównych problemów społeczno-gospodarczych współczesnej Europy, a szczególnie Niemiec. Jedną z podstawowych trudności w jego rozwiązaniu jest fakt, 
że w kierunku Europy napływa nie tylko fala uchodźców. Oprócz osób uciekających przed wojną i prześladowaniem, w grupie migrantów podróżują także osoby chcące poprawić swój status materialny. Występuje zatem zjawisko mieszanej migracji. W związku z tym, $\mathrm{w}$ niniejszym artykule, używane będzie pojęcie kryzys migracyjny, nie zaś kryzys uchodźczy.

Celem niniejszego artykułu jest ukazanie zależności między niemiecką polityką socjalną a przypływami ludnościowymi $\mathrm{w}$ tym państwie. Analizie zostanie poddany okres od początku 2011 roku, czyli od momentu uznawanego za rozpoczęcie kryzysu migracyjnego w Europie, do końca 2016 roku.

W Sekcji 2. dokonany został przegląd literatury przedmiotu. W Sekcji 3. zawarty został opis wykorzystanych metod. W Sekcji 4. przedstawione zostały wyniki przeprowadzonej analizy, które zostały podsumowane w Sekcji 5.

\section{Przegląd literatury}

$Z$ uwagi na fakt, że obecny kryzys migracyjny jest wydarzeniem trwającym zaledwie od kilku lat, w literaturze przedmiotu istnieje luka poznawcza.

K. Strachota (2015) porusza kwestię bezpośrednich przyczyn powstania kryzysu migracyjnego zaliczając do nich m.in.: załamanie się porządku politycznego i społecznego na Bliskim Wschodzie oraz powstanie tzw. Państwa Islamskiego.

P. Sasnal (2015) przedstawia czynniki występujące $w$ państwach pochodzenia masowych migracji, które miały wpływ na decyzję obywateli o opuszczeniu ojczyzny. Zalicza do nich przede wszystkim: wojny, terroryzm, prześladowania, brak perspektyw rozwoju oraz biedę. Wskazuje zatem, że wśród migrantów znajdują się zarówno ci, którzy uciekali przed niebezpieczeństwem, jak i ci, którzy chcieli poprawić swoją sytuację ekonomiczną.

W. Wilk (2016) opisuje wydarzenia w Syrii, czyli państwa, z którego pochodziła największa liczba uchodźców w analizowanych latach. Podkreśla, że mająca tam miejsce wojna między czterema różnymi stronami konfliktu, spowodowała ucieczkę znacznej części obywateli do Europy. Powodami wyboru takiego akurat kierunku migracji, według niego były m.in.: rozbudowana pomoc socjalna dla uchodźców w rozwiniętych państwach europejskich, perspektywa znalezienia dobrze płatnej pracy oraz uzyskania dobrej edukacji dla dzieci.

S.K. Mazur (2015) przedstawia odmienność zdań szefów rządów państw Unii Europejskiej (UE), dotyczącą kwestii przyjmowania azylantów. Jak zauważa, Niemcy od momentu nasilenia się kryzysu, były najbardziej przychylne względem napływających uchodźców. W związku z tym przedstawiciele wielu państw członkowskich UE uważali, że to właśnie na tym państwie spoczywa największy obowiązek ich przyjęcia.

M. Skóra (2015) prezentuje kontekst społeczno-historyczny niemieckiej polityki migracyjnej. Zaznacza, że poczucie winy niemieckiego narodu za wydarzenia II wojny światowej, jak również zła sytuacja demograficzna państwa, miały największy wpływ na całokształt działań podejmowanych przez przedstawicieli tego państwa w czasie obecnego kryzysu migracyjnego. B. Koszel (2016) wskazuje natomiast na jeden $z$ czynników przyciągających uchodźców do Niemiec, którym były wypowiedzi i działania podjęte przez kanclerz A. Merkel, a konkretnie prowadzona przez nią polityka otwartych granic dla syryjskich migrantów.

K. Szubart (2015) podejmuje kwestie niemieckiej polityki socjalnej wobec azylantów i uchodźców. Porównuje ich system świadczeń $z$ tego rodzaju pomocą finansową $w$ innych państwach europejkkich. Dochodzi do wniosku, że niemiecki system jest jednym $z$ najlepszych w Europie.

\section{Metody}

Całość badania została przeprowadzona za pomocą oceny mierników ilościowych. Analizie zostały poddane dane Eurostat (2017) oraz Federalnego Urzędu Statystycznego Niemiec (Statistisches Bundesamt Deutschland, 2017) dotyczące wniosków o azyl oraz przepływów 
migracyjnych, jak również ustawy Deutscher Bundestagu dotyczące świadczeń socjalnych dla uchodźców. Podjęcie tej kwestii było również możliwe dzięki zebraniu i przeanalizowaniu literatury przedmiotu.

\section{Wyniki badania}

\subsection{Geneza kryzysu migracyjnego w Europie}

Trwający kryzys migracyjny jest największym kryzysem humanitarnym XXI wieku. Jego genezy należy szukać w tzw. „Arabskiej Wiośnie Ludów", która rozpoczęła się na przełomie 2010 i 2011 roku w północnej części Afryki, a konkretnie w Egipcie oraz Tunezji. W państwach tych, obywatele obalili władze dotychczasowych dyktatorów. Sukces tych rewolucji zachęcił również mieszkańców państw sąsiednich do rozpoczęcia działań przeciwko autorytarnym rządom.

W 2011 roku w Syrii rozpoczęła się wojna domowa. Dyktator B. Al-Asad był przedstawicielem alawitów, którzy w Syrii stanowili mniejszość. Siły opozycyjne natomiast tworzyła sunnicka większość, która chciała wymóc ustąpienie B. Al-Asada, wprowadzenie pełni praw obywatelskich oraz dokonanie reform politycznych. Początkowo wojna odbywała się tylko między tymi dwiema stronami konfliktu, jednak wraz $z$ upływem czasu włączyło się w nią również tzw. Państwo Islamskie oraz Kurdowie. Każda $z$ tych grup posiadała odmienne powody i cele swojej walki. Tak duża polaryzacja konfliktu, nie sprzyjała jego zakończeniu, a wręcz była przyczyną coraz większej eskalacji. Wojna pochłonęła 300 tys. ofiar, zniszczyła infrastrukturę, spowodowała powstanie ogromnej biedy i głodu. Pomoc humanitarna organizacji międzynarodowych była często blokowana na terytorium państwa. Wszystkie te czynniki spowodowały, że w latach 2011-2016 4,8 mln obywateli syryjskich wyemigrowało $z$ tego państwa. Jest to obecnie najliczniejsza grupa uchodźców na świecie. Głównymi kierunkami migracji były: Liban, Jordania oraz Turcja (Amnesty International, 2017, s. 88). Ponad 0,5 mln $z$ nich dotarło jed- nak aż do Europy. Taki cel migracji był szczególnie popularny w latach 2014-2016.

W ostatnim okresie, głównym agresorem, wzniecającym niepokój na Bliskim Wschodzie było tzw. Państwo Islamskie. Jest to organizacja terrorystyczna przez długie lata związana z Al-Kaidą. W latach 2013-2014 dokonała ona zajęcia znacznego terytorium na Bliskim Wschodzie, proklamując przy tym własne państwo, nieuznawane i potępiane na arenie międzynarodowej (Strachota, 2015, s. 8). Od 1 stycznia 2014 roku, tzw. Państwo Islamskie rozpoczęło swoją ofensywę na terytorium Iraku, zajmując jego znaczną część. Podbój dokonywany był łącznie $z$ aktami terroru takimi, jak: eksterminacja ludności cywilnej, masowe gwalty oraz czystki religijne (Strachota, 2015, s. 12). Ludność iracka w ucieczce przed wojną i prześladowaniami, często zmuszona była szukać schronienia w innych państwach.

Sytuacje powodujące masową migrację, występowały również $w$ takich państwach Afryki, jak Erytrea czy Nigeria oraz w pewnych państwach Azji.

Erytrea to państwo, z którego emigrowała największa liczba osób spośród państw afrykańskich. Przyczyną tego był całkowity brak jakichkolwiek wolności i swobód obywatelskich, jak również łamanie praw człowieka, które występowało tam na porządku dziennym. W Nigerii głównym, choć nie jedynym, czynnikiem powodującym opuszczanie państwa była natomiast kwestia ekonomiczna (Sasnal, 2015, s. 45).

Spośród azjatyckich państw, największa liczba migrantów pochodziła z Afganistanu oraz Pakistanu. Afgańczycy przez wiele lat stanowili największą grupę uchodźców na świecie, obecnie znajdują się tylko za Syryjczykami. Afganistan od wielu lat jest niestabilny politycznie i ekonomicznie. Od zakończenia misji Organizacji Traktatu Północnoatlantyckiego (North Atlantic Treaty Organization - NATO) w 2014 roku, której celem było obalenie rządu sprzyjającego talibom, sytuacja $\mathrm{w}$ państwie jeszcze się pogorszyła (Sasnal, 2015, s. 45). Brak pokoju, wyniszczenie ekonomiczne państwa i ciągłe poczucie zagrożenia, stanowiły przyczynę emigracji dużej liczby ludności po- 
szukującej lepszego miejsca do życia. Podobne motywy migracji dotyczyły również Pakistańczyków, w których państwie dochodziło do częstych zamachów terrorystycznych, przeprowadzanych przez talibów oraz prześladowań na tle religijnym.

Kluczowym jednak czynnikiem, przyczyniającym się do powstania kryzysu migracyjnego w Europie, a w konsekwencji również $\mathrm{w}$ Niemczech, była wojna $\mathrm{w}$ Libii. Jest to państwo będące głównym punktem szlaku migracyjnego z Afryki do Europy. W 2011 roku rozpoczęła się tam wojna domowa między siłami rządowymi, wiernymi dyktatorowi M. Kaddafiemu, a oddziałami rebeliantów walczącymi o poprawę warunków życia oraz zwiększenie zakresu swobód obywatelskich. Próba obalenia władzy zakończyła się sukcesem. Nie spowodowało to jednak długoterminowego ustabilizowania się sytuacji w tym państwie. W 2014 roku pod wpływem konfliktu wewnętrznego o władzę, działania zbrojne zostały wznowione. Swoją operacje na tym terytorium rozpoczęło również nowo powstałe w tamtym okresie tzw. Państwo Islamskie, co jeszcze bardziej zaogniło sytuację. Państwo to było $w$ analizowanym okresie jednym z najbardziej niestabilnych na świecie, co powodowało dużą trudność w kontroli przepływów ludności dokonujących się na jego terytorium. Jego destabilizacja miała zatem znaczący wpływ na obranie Europy jako kierunku migracji przez znaczną część uchodźców. Docelowo największa ich grupa dotarła do Republiki Federalnej Niemiec (RFN).

\subsection{Różnica między uchodźcą a migrantem ekonomicznym}

Pierwszym i podstawowym zagadnieniem, w odniesieniu do masowej migracji w kierunku Europy, była kwestia rozróżnienia między migrantem ekonomicznym a uchodźcą. Według Konwencji genewskiej (1951), uchodźcą jest osoba, która „na skutek uzasadnionej obawy przed prześladowaniem $z$ powodu swojej rasy, religii, narodowości, przynależności do określonej grupy społecznej lub z powodu przekonań politycznych przebywa poza granicami państwa, którego jest obywatelem, i nie może lub nie chce $z$ powodu tych obaw korzystać $z$ ochrony tego państwa, albo która nie ma żadnego obywatelstwa i znajdując się na skutek podobnych zdarzeń, poza państwem swojego dawnego stałego zamieszkania nie może lub nie chce $z$ powodu tych obaw powrócić do tego państwa”. Jest to zatem osoba zmuszona przez warunki od niej niezależne, do opuszczenia państwa macierzystego i przebywania poza jego granicami. Cecha ta odróżnia uchodźcę od migranta, którego Międzynarodowa Organizacja ds. Migracji (IOM, 2017), określa jako każdą osobę, która przemieszcza się lub przemieściła się przez granice międzynarodowe lub w ramach danego państwa ze swojego stałego miejsca zamieszkania bez względu na:

- status prawny,

- dobrowolność przemieszczenia,

- powód przemieszczenia,

- czas pozostawania w nowym miejscu.

Definicja ta obejmuje zatem większy zakres osób, niż definicja uchodźcy. Osobą, która chce być uznana za uchodźcę, ale ciągle czeka na decyzję o przyznaniu jej tego statusu, jest azylant (Mazur, 2015, s. 8).

Rozróżnienie to jest kluczowe dla państwa przyjmującego, w którym złożony został wniosek o azyl. W stosunku do migrantów stosowane jest wyłącznie prawo krajowe, zaś w stosunku do uchodźców występuje również obowiązek stosowania przepisów międzynarodowych. Państwo przyjmujące ma zatem prawo odmowy wstępu na swoje terytorium imigrantom ekonomicznym, jednak ma obowiązek przyjęcia uchodźców (Potyrała, 2015, s. 13). Dla ustalenia tego, czy dana osoba ucieka z państwa przed prześladowaniem, czy raczej szuka poprawy jakości życia, używane jest pojęcie państwa bezpiecznego. Według Konwencji genewskiej (1951), opuszczenie tego rodzaju państwa nie uprawnia do ubiegania się o status uchodźcy. UE precyzuje definicję państwa bezpiecznego, jako takiego, w którym życie i wolność nie są zagrożone $z$ powodu rasy, religii, narodowości, przynależności do określonej grupy społecznej lub utożsamiania się z określonymi poglądami politycznymi, nie 
występuje $\mathrm{w}$ nim ryzyko odniesienia poważnej szkody dla uchodźcy (tortur, nieludzkiego traktowania, zagrożenia $z$ powodu masowej przemocy wywołanej konfliktem), państwo to samo nie dostarcza uchodźców, zapewniona jest zasada niewydalania uchodźców do państw pochodzenia oraz istnieje możliwość ubiegania się o status uchodźcy i otrzymania opieki zgodnie z Konwencją genewską (1951) (Dyrektywa, 2013). Państwa takie, jak: Syria, Libia, czy Irak do takiej grupy się nie zaliczają. Emigracja $z$ tych państw uprawniała zatem do ubiegania się o status uchodźcy. Każdy wniosek o azyl był jednak rozpatrywany indywidualnie, bo motywy opuszczenia państwa mogły być różne. Konwencja genewska (1951) nakazuje osobie pragnącej ubiegać się o status uchodźcy, aby w pierwszym, bezpiecznym państwie, w którym znajdzie się po opuszczeniu swojej ojczyzny, złożyła wniosek o jego nadanie. W przypadku ludności napływającej do Europy powstała w tej kwestii duża niezgodność. Podróżując najczęściej szlakiem od Libii przez Morze Śródziemne, docierała ona początkowo na terytorium Włoch lub Grecji, jednak tylko niewielka liczba osób złożyła tam wnioski o azyl. Większość osób starała się dotrzeć do bardziej rozwiniętych państw takich, jak: Szwecja, Francja, Wielka Brytania, przede wszystkim Niemcy i dopiero tam uzyskać status uchodźcy. Taka sytuacja zrodziła pytania o to, czy osoby przybywające do Europy to uchodźcy, czy migranci ekonomiczni oraz dlaczego akurat Niemcy są głównym celem ich wędrówki.

\subsection{Niemiecka polityka migracyjna}

RFN po II wojnie światowej rozpoczęła politykę otwartości wobec imigrantów tak, aby zmazać obraz państwa wrogiego wobec innych nacji (Skóra, 2015, s. 3). Wiązało się to również ze sporym zapotrzebowaniem na siłę roboczą, jaka występowała $\mathrm{w}$ tym państwie $\mathrm{w}$ latach 50., 60. i 70. XX w. Do Niemiec zaczęła napływać ludność nie tylko z państw europejskich, lecz także spora grupa obywateli Turcji, Tunezji i Maroka. Od początku pojawił się jednak problem, jak przystosować przybywającą ludność o odmiennej kulturze do warunków i zasad życia w Niemczech. Pojawiła się koncepcja multikulturalizmu, inaczej nazywana również ideą wielokulturowości. Zakładała ona wzajemne współistnienie przedstawicieli różnych kultur na ograniczonym obszarze (Nikitorowicz, 2010, s. 370). Wszystkie kultury miały ze sobą koegzystować. W państwie, w którym przez pewien czas wszelka odmienność była niszczona i likwidowana, pomysł ten został uznany za słuszny i wdrożony w życie w stosunku do napływających imigrantów. Był to jeden $z$ ważnych czynników przyciągających uchodźców $z$ różnych państw, również w latach poprzedzających obecny kryzys migracyjny. Rozpad Jugosławii i konflikt zbrojny w Bośni i Hercegowinie spowodowal, że wniosek o azyl w Niemczech złożyło aż 438 tys. osób z obszarów objętych walkami (Koszel, 2016, s. 147). Państwo to było zatem docelowe, już podczas poprzednich przemieszczeń migracyjnych.

Początkowo niemieckie działania wobec imigrantów wpisywały się $w$ politykę całej UE, która już w 1999 roku zobowiązała się do utworzenia Wspólnego Europejskiego Systemu Azylowego (WESA), w celu kontrolowania masowych migracji. W 2003 roku wydano rozporządzenie Dublin II określające zasadę, że tylko jedno państwo członkowskie jest odpowiedzialne za rozpatrywanie wniosku o azyl, tym samym uniemożliwiając składanie kilku wniosków w różnych państwach. W 2005 roku powołano Europejską Agencję Straży Granicznej i Przybrzeżnej (Frontières extérieures - Frontex), której zadaniem miała być kontrola granic zewnętrznych UE. W 2008 roku zatwierdzono Europejski Pakt o Imigracji i Azylu (2008), którego celami były:

- organizowanie legalnej imigracji, biorąc pod uwagę priorytety, potrzeby i zdolności przyjmowania określane przez każde państwo członkowskie i sprzyjanie integracji;

- zwalczanie nielegalnej imigracji, zwłaszcza poprzez zapewnienie powrotów cudzoziemców przebywających nielegalnie do państw pochodzenia lub tranzytu; 
- zwiększenie skuteczności

kontroli granicznych;

- budowa Europy, która będzie miejscem azylu;

- stworzenie globalnego partnerstwa z państwami pochodzenia i tranzytu przez sprzyjanie synergii między migracją a rozwojem.

W obliczu narastających problemów ze wzmożonym napływem migrantów do Europy, 1 stycznia 2014 roku weszło w życie rozporządzenie Dublin III, które nakazywało, aby cudzoziemcy byli zawracani do państw odpowiedzialnych za rozpatrzenie ich wniosków uchodźczych.

W 2015 roku nastąpiło jednak największe nasilenie kryzysu migracyjnego. W takiej sytuacji zawarto porozumienie między kanclerz Niemiec A. Merkel a kanclerzem Austrii W. Faymannem o okresowym wstrzymaniu stosowania Konwencji dublińskiej i przyjęciu azylantów bez przeprowadzania procedur biurokratycznych. Zgodnie $z$ tymi ustaleniami, 25 sierpnia 2015 roku Federalny Urząd ds. Migracji i Uchodźców (Bundesamt für Migration und Flüchtlinge - BAMF) zapewnit, że w stosunku do migrantów syryjskich nie będą wykorzystywane ustalenia UE w zakresie azylu i imigracji. Była to bezpośrednia reakcja na wydarzenia, jakie miały miejsce $\mathrm{w}$ Budapeszcie, gdzie od dłuższego czasu ogromna ilość migrantów oczekiwała na możliwość wyjazdu z dworca kolejowego Keleti. Decyzja ta, spowodowana wyjątkową sytuacją i kierowana przesłankami humanitarnymi, miała być tylko jednorazową akcją. Została jednak odebrana jako zaproszenie do masowych przyjazdów (Hildebrandt i Ulrich, 2015). Kilka dni później, kanclerz A. Merkel, w pewnym sensie potwierdziła te oczekiwania podczas konferencji prasowej w Berlinie. Wypowiedziane wtedy przez nią słowa "damy radę" ("wir schaffen das"), były niejako hasłem niemieckiej polityki otwartości wobec uchodźców (Bannas, 2015).

W skutek tych działań, przypływy migracyjne jeszcze się zwiększyły, co zmusiło rząd niemiecki do wprowadzenia pewnych obostrzeń. 13 września 2015 roku przywrócono kontrolę na granicy niemiecko-austriackiej, a przybywającym imigrantom nakazano zapoznać się $z$ katalogiem praw i obowiązków wynikającym $z$ przebywania na terytorium Niemiec. Sytuację tę starali się również wykorzystać obywatele państw bałkańskich, którzy migrowali w celu uzyskania statusu uchodźcy. Wobec tego, Niemcy oficjalnie uznały Serbię, Macedonię, Bośnię i Hercegowinę, Albanię, Kosowo i Czarnogórę za państwa bezpieczne. W związku z tym, wnioski o azyl osób z tych państw były rozpatrywane $w$ trybie przyspieszonym i miały bardzo niewielkie szanse na pozytywną decyzję.

Niemiecką politykę migracyjną łatwiej zrozumieć z punktu widzenia sytuacji demograficzno-społecznej. Niemcy od 1991 roku posiadały bardzo niski wskaźnik dzietności wynoszący poniżej 1,4 (World Bank, 2017). Starzejące się społeczeństwo nie zapewniało zastępowalności pokoleń. Nastąpiła konieczność rozbudowy systemu opieki zdrowotnej i społecznej, jak również zwiększenia granicy wieku emerytalnego z 65 do 67 lat. Gdy w 2011 roku rozpoczął się kryzys migracyjny w Europie, pojawiły się głosy, że jest to szansa dla Niemiec na zahamowanie tego negatywnego trendu.

Niemiecką polityką otwartych granic dla uchodźców, nie można jednak całkowicie wytłumaczyć wybierania akurat tego państwa, jako głównego kierunku migracji spośród wszystkich państw UE. Rozbudowane i wysokie, w stosunku do innych państw europejskich, świadczenia socjalne w Niemczech dla osób starających się o azyl, a przede wszystkim dla tych, którym udzielono azylu, były w tym wyborze jednym z decydujących czynników.

\section{4. Świadczenia socjalne dla uchodźców w Niemczech}

Niemiecka polityka socjalna, $\mathrm{w}$ stosunku do osób ubiegających się o azyl, została określona w ustawie azylowej Asylbewerberleistungsgesetz zatwierdzonej w 1993 roku i opublikowanej w 1997 roku. Zgodnie z nią, każdy przybysz do RFN, który złożył wniosek o azyl, dostawał przez pierwsze 3 miesiące pobytu w ośrodku imigracyjnym pomoc, zarówno w postaci rze- 
czowej, jak i finansowej. Azylant miał zatem zapewnione ze strony państwa: zakwaterowanie, jedzenie, podstawowe środki higieny, ubranie oraz obuwie (Asylbewerberleistungsgesetz, 1997). Wysokość środków pieniężnych była uzależniona od wieku i statusu rodzinnego imigranta. Ustalone były stawki na następującym poziomie (Asylbewerberleistungsgesetz, 1997):

- osoby samotne - 135 EUR;

- osoby dorosłe prowadzące wspólne gospodarstwo domowe - 122 EUR;

- dodatkowe osoby w rodzinie - 113 EUR;

- dzieci od 15 do 18 roku życia - 76 EUR;

- dzieci od 7 do 14 roku życia - 83 EUR;

- dzieci poniżej 6 roku życia - 79 EUR.

Po upływie 3 miesięcy, jeżeli nadal nie została wydana decyzja dotycząca przydzielenie azylu, osoba zainteresowana opuszczała ośrodek dla uchodźców. Następnie była kwaterowana $z$ innymi migrantami lub otrzymywała mieszkanie. Zaczęły również obowiązywać ją nowe stawki świadczeń socjalnych (Asylbewerberleistungsgesetz, 1997):

- osoby samotne - 216 EUR;

- osoby dorosłe prowadzące wspólne gospodarstwo domowe - 194 EUR;

- dodatkowe osoby w rodzinie - 174 EUR;

- dzieci od 15 do 18 roku życia - 198 EUR;

- dzieci od 7 do 14 roku życia - 157 EUR;

- dzieci poniżej 6 roku życia - 133 EUR.

Jeżeli decyzja, jaką otrzymał azylant okazała się pozytywna, uzyskiwał on status uchodźcy i otrzymywał mieszkanie komunalne. Koszty zakwaterowania (oraz dodatkowe opłaty m.in. za ogrzewanie), nadal opłacane były przez państwo niemieckie (Szubart, 2015, s. 13). Od tego momentu, jako uchodźcę zaczynały go również obowiązywać takie same zasady otrzymywania pomocy socjalnej ze strony państwa, jak rodowitych Niemców. Nie podlegał on zatem już pod ustawę azylową, lecz pod drugą księge kodeksu prawa socjalnego Sozialgesetzbuch II. Otrzymywał zasiłek dla bezrobotnych, który nosił nazwę Arbeitslosengeld II, inaczej zwany również Hartz IV. Jego stawki w analizowanych latach 2011-2016 były $z$ roku na rok podnoszone (tabela 1.).
Dodatkową korzyścią dla odbiorców zasiłku Hartz IV był fakt, że w wielu miastach otrzymywali oni zniżki na przejazdy komunikacją miejską, a także na bilety wstępu do ośrodków kultury. Świadczenia socjalne w takiej wysokości i formie, zapewniały minimum egzystencji według orzeczeń Federalnego Trybunału Konstytucyjnego. W związku $z$ tym, nie istniała jakakolwiek możliwość ich zmniejszenia.

RFN pod względem zakresu wsparcia finansowego dla azylantów zdecydowanie wyprzedza takie państwa UE, jak Estonia i Łotwa, gdzie otrzymywali oni równowartość 2,15 EUR dziennie, lub tygodniowo 10 EUR na Litwie i 7125 HUF (22,76 EUR) na Węgrzech (Szubart, 2015 s. 14).

$\mathrm{W}$ południowych państwach europejskich sytuacja nie wyglądała lepiej. W Hiszpanii kwota pomocy dla azylantów wynosiła 51,60 EUR miesięcznie, zaś we Włoszech, dla osób przebywających $\mathrm{w}$ ośrodkach dla nich przeznaczonych, 75 EUR miesięcznie.

W najbardziej rozwiniętych państwach UE, pomoc dla osób starających się o azyl była minimalnie mniejsza od niemieckiej, ze względu na fakt, że nie zawierała świadczeń poza pieniężnych. W Szwecji otrzymywali oni równowartość około 223 EUR miesięcznie (Skandynawia Info, 2017). W Holandii mogli liczyć na pomoc w wysokości 20-45 EUR tygodniowo na jedzenie oraz dodatkowe 13 EUR kieszonkowego. W Luksemburgu maksymalną kwotą jaką otrzymywali było 225 EUR. We Francji natomiast pomoc socjalna dla azylantów była nawet teoretycznie znacznie większa (343,5 EUR miesięcznie), jednak również nie zawierała bezpłatnych dodatków $\mathrm{w}$ postaci wyżywienia, czy odzieży (Szubart, 2015, s. 15).

Wysokość świadczeń socjalnych dla osób, które uzyskały już status uchodźcy, W Danii były znacznie większe, niż w Niemczech. Do sierpnia 2015 roku mogli oni otrzymać równowartość 1450 EUR miesięcznie, we wrześniu kwota ta została zmniejszona do 800 EUR (TV2, 2015). Nadal jednak było to państwo wiodące prym w Europie, biorąc pod uwagę wysokość tego rodzaju świadczeń. 
Również Szwecja oferowała większą pomoc finansową dla uchodźców niż Niemcy, zapewniając im równowartość 670 EUR miesięcznie (Skandynawia Info, 2017). Nie zmienia to jednak faktu, że pod względem zakresu wsparcia finansowego dla imigrantów, RFN znajdywało się $\mathrm{w}$ czołówce najbardziej uprzemysłowionych państw Europy Zachodniej (Szubart, 2015, s.15) Według systemu Hartz, czteroosobowa rodzina, mogła w 2016 roku otrzymywać miesięcznie łącznie 1340 EUR, nie musząc dodatkowo ponosić kosztów utrzymania mieszkania. Nie dziwi zatem fakt, że migranci w ogromnej liczbie starli się dotrzeć właśnie do państwa nadreńskiego.

\subsection{Napływ migrantów do Niemiec w latach 2011-2016}

Wzrost lub spadek liczby ludności uwzględniający zarówno imigracje, jak i emigracje $z$ danego państwa przedstawiony jest przez saldo migracyjne, które jest różnicą między wielkością napływu i odpływu migrantów (Gmaj, 2012, s. 15). Całkowite przepływy ludnościowe w Europie, również w Niemczech, były $w$ ostatnich latach mocno determinowane przez ruchy migracyjne uchodźców. $Z$ każdym rokiem saldo migracji $w$ Niemczech wzrastało, jednak rekordowym pod tym względem był 2015 rok, kiedy nadwyżka migracyjna osiągnęła liczbę 1,14 $\mathrm{mln}$ osób (wykres 1.). Był to najwyższy poziom w całej historii Niemiec (Zeit, 2016). Duży wpływ na taki wynik miały migracje wewnątrzunijne do Niemiec z państw takich, jak Rumunia czy Bułgaria, jednak bardzo znaczący udział w tej liczbie, miały również napływy azylantów (Statistisches Bundesamt Deutschland, 2017).

W tabeli 2. została zestawiona liczba wniosków o udzielenie azylu w Niemczech na tle innych państw członkowskich UE. Od początku kryzysu migracyjnego w Europie, Niemcy były jednym z głównych celów wędrówki uchodźców. Ilość wniosków o azyl zarejestrowanych w tym państwie w 2011 roku przekraczała 53 tys., tylko we Francji złożono ich wówczas więcej. W latach
2012-2013 w RFN, składano już najwięcej wniosków o azyl spośród wszystkich państw UE. W 2014 roku, kiedy to kryzys migracyjny w Europie znacząco się nasilit, Niemcy były już zdecydowanie najczęściej wybieranym kierunkiem migracji uchodźców. Ilość wniosków o azyl tam złożonych przekraczała 202 tys. i była ponad dwukrotnie większa od drugiego państwa pod tym względem w UE, czyli Szwecji. W 2015 roku liczba uchodźców przybyłych z terenów Afryki Północnej i Bliskiego Wschodu do Europy była najwyższa. Liczba azylantów przybyłych na terytorium Niemiec zwiększyła się natomiast ponad dwukrotnie w porównaniu z 2014 rokiem, przekraczając 476 tys. i była znacząco, ponad dwukrotnie wyższa, niż na Węgrzech, które $\mathrm{w}$ tym roku były drugim państwem UE pod względem liczby złożonych wniosków o azyl. Tak duży przypływ azylantów w pewnym stopniu wyjaśnia również znaczny wzrost salda migracyjnego w Niemczech w 2015 roku (wykres 1.). 2016 rok był jednak rekordowy pod względem liczby wniosków złożonych o azyl w tym państwie, która wynosiła ponad 745 tys., czyli ponad sześć razy więcej niż we Włoszech, które były drugie pod tym względem.

Dane ukazujące udział liczby wniosków o azyl złożonych w Niemczech w całkowitej liczbie wniosków o azyl złożonych na terytorium UE w analizowanych latach, zostały przedstawione na wykresie 2.

W każdym $z$ analizowanych lat, udział liczby wniosków o udzielnie azylu w Niemczech w całkowitej liczbie złożonych wniosków o udzielnie azylu na terytorium UE, wynosił ponad $15 \%$. Poziom ten $z$ roku na rok wzrastał, a w 2016 roku osiągnął prawie 60\%. Oznacza to, że Niemcy były postrzegane przez azylantów jako miejsce dla nich bardziej atrakcyjne do życia, w porównaniu $z$ wszystkimi innymi państwami UE łącznie. Można zauważyć również, że liczba azylantów rosła wraz z rokroczną podwyżką świadczeń socjalnych Hartz IV dla uchodźców w Niemczech.

Jak zostało wspomniane w Sekcji 4.4., Dania i Szwecja oferowały wyższe świadczenia socjalne dla uchodźców niż Niemcy. $\mathrm{Na}$ wykresie 3. zostały przedstawione dane 
dotyczące liczby wniosków o azyl złożonych w tych trzech państwach $w$ analizowanych latach, w stosunku do ich liczby mieszkańców. Dania, mimo największych zasiłków oferowanych uchodźcom, miała mniejszą ilość złożonych wniosków o azyl w stosunku do liczby mieszkańców niż Niemcy i Szwecja. Mogło mieć to związek z tym, że duńskie rozwiązania socjalne wymuszały podjęcie działań i wysiłków, ze strony osoby otrzymującej zapomoge (Szubart, 2015, s. 15), jak również z pewnych czynników pozaekonomicznych. Niemcy oprócz wysokich świadczeń socjalnych, w stosunku do innych państw, posiadały zadomowioną już społeczność muzułmańską, będącą wynikiem poprzednich przemieszczeń migracyjnych, jak również prowadziły przez jakiś czas politykę otwartych granic dla uchodźców. Szwecja natomiast już w 2013 roku oznajmiła, że wszyscy uchodźcy z terenów objętych wojną, otrzymają stałe pozwolenia na pobyt na jej terytorium. We wszystkich tych trzech państwach, liczba złożonych wniosków o azyl w analizowanych latach stosunku do ogółu mieszkańców danego państwa, wynosiła ponad $1 \%$ i był to jeden $z$ najwyższych poziomów pod tym względem w Europie.

W grudniu 2016 roku Niemiecki Instytut Badań Rynku Pracy i Zatrudnienia podal, że jedynie 3\% migrantów spoza UE, którzy złożyli wniosek o azyl w Niemczech, podjęło pracę zawodową (wSensie.pl, 2016). Reszta azylantów utrzymywała się z zasiłków. $\mathrm{Na}$ podstawie tego, można wyciągnąć wniosek, że duży wpływ na wybór decyzji o takim kierunku migracji, miała właśnie wysokość świadczeń socjalnych.

Duży napływ uchodźców w latach 20112016 był jednak również bardzo obciążający dla budżetu niemieckiego państwa. Powodował również powstawanie pewnych problemów natury społecznej. W samym 2015 roku wydatki na utrzymanie azylantów wyniosły 5,3 mld EUR. Ośrodki dla uchodźców często były przepełnione, co powodowało powstawanie przemocy między azylantami na tle religijnym, narodowym i etnicznym, ale również seksualnym (Szubart, 2015, s. 19). Wnioski o azyl rozpatrywane były bardzo długo, co utrudniało zwalnianie miejsc dla przybywających osób w przeludnionych ośrodkach. W takiej sytuacji 19 września 2016 roku kanclerz A. Merkel oficjalnie przyznała się do błędu i powiedziała, że „Niemcy nie były gotowe na przyjęcie miliona migrantów".

\section{Zakończenie}

Niemiecką polityka socjalna była jednym $z$ głównych czynników przyciągających uchodźców do tego państwa, jednak nie należała do bezpośrednich przyczyn powstania kryzysu migracyjnego. Wynikały one bowiem $z$ wojen i braku stabilności politycznej oraz ekonomicznej na terytorium Afryki Północnej oraz Bliskiego Wschodu, a nie działania jakiekolwiek rządu państwa europejskiego, w tym również niemieckiego. Podstawowym problemem pozostawała kwestia tego, czy osoba składającą wniosek o azyl, była uchodźcą, czy migrantem ekonomicznym. Istniało wiele czynników, które mogły mieć wpływ na wybranie przez znaczną część azylantów państwa nadreńskiego, jako głównego kierunku migracji, w wyniku pro imigracyjnych działań rządu. Mocno rozbudowany zakres świadczeń socjalnych, w porównaniu do innych państw europejskich, zarówno w postaci rzeczowej, jak i finansowej, był jednak jednym z najważniejszych elementów tej polityki, jak również jedną z głównych przyczyn znacznego natężenia kryzysu migracyjnego w Niemczech. W 2016 roku 60\% wszystkich wniosków o azyl, złożonych na terytorium UE, została zarejestrowana $w$ państwie niemieckim. Jak wspomniano, duży wpływ na podjęcie decyzji o kierunku migracji przez azylantów miała wysokość świadczeń socjalnych, o czym świadczą dane Niemieckiego Instytutu Badań Rynku Pracy i Zatrudnienia. Według nich tylko $3 \%$ osób starających się o azyl podjęło pracę. Reszta utrzymywała się wyłącznie z zasiłków. Spowodowało to spore obciążenie dla budżetu, jak również powstawanie problemów natury społecznej. Należy jednakże pamiętać, że działania mające na celu ograniczenie migracji, nie mogą polegać na zmniejszeniu świadczeń socjalnych, wyrażonych w Hartz 
IV, gdyż według orzeczeń Federalnego Trybunału Konstytucyjnego zostały one uznane za zapewniające minimum egzystencji.

\section{Bibliografia}

Amnesty International. (2016). Raport roczny Amnesty International 2015/2016. Pobrane 06.03.2017 z https://amnesty.org.pl.

Asylbewerberleistungsgesetz in der Fassung der Bekanntmachung vom 5. August 1997 (BGBl. I S. 2022).

Bannas, G. (2015). Merkel: „Wir schaffen das”. Pobrane 12.05.2017 z http://www.faz.net.

Dojczland.info (2017). Pobrane 12.03.2017 z https://dojczland.info.

Dyrektywa Parlamentu Europejskiego i Rady 2013/32/UE z dnia 26 czerwca 2013 roku w sprawie wspólnych procedur udzielania i cofania ochrony międzynarodowej (Dz.Urz. UE L 180 z 29.6.2013).

Encyklopedia PWN. (2017). Pobrane 04.03.2017 z http://encyklopedia.pwn.pl.

Europejski pakt o imigracji i azylu $z$ dnia 24 września 2008 roku (nieopublikowany w Dz.Urz.).

Eurostat. (2017). Pobrane 11.03.2017 $z$ http:// ec.europa.eu.

Gmaj, K. (2012). Wprowadzenie w zagadnienia migracji i integracji. W: A. Chmielecka (red.), Od migracji do integracji. Vademecum. Warszawa: Helsińska Fundacja Praw Człowieka.

Hildebrandt, T. i Ulrich, B. (2015). Im Auge des Orkans. Pobrane 10.03.2017 z http:// www.welt.de.

IOM. (2017). Key Migration terms. Pobrane 09.03.2017 z http://www.iom.int.

Konwencja dotycząca statusu uchodźców, sporządzona w Genewie dnia 28 lipca 1951 roku (Dz.U. $1991 \mathrm{nr} 119$ poz. 515).

Koszel, B. (2016). Unia Europejska, Niemcy i problem uchodźców (2014-2016). Rocznik Integracji Europejskiej, 10.

Mazur, S.K. (2015). Kryzys na granicach Europy i jego wpływ na strukturę Unii Europejskiej w latach 2011-2015. W: S.K. Mazur (red.), Unia Europejska a migracje: szanse i wyzwania. Rzeszów: Punkt Informacji Europejskiej Europe Direct.
Nikitorowicz, J. (2010). Grupy etniczne w wielokulturowym świecie. Sopot: Gdańskie Wydawnictwo Psychologiczne.

Potyrała, A. (2015). W poszukiwaniu solidarności. Unia Europejska wobec kryzysu migracyjnego 2015. Przegląd Politologiczny, 4. doi:10.14746/ pp.2015.20.4.3.

Sasnal, P. (red.). (2015). Niekontrolowane migracje do Unii Europejskiej - implikacje dla Polski. Warszawa: PISM.

Skandynawia Info. (2017). Pobrane 15.05.2017 $z$ http://skandynawiainfo.pl.

Skóra, M. (2015). Republika Federalna Niemiec a kwestia imigrancka. Biuletyn Niemiecki, 59. Pobrane 10.03.2017 z http://fwpn.org.pl.

Statistisches Bundesamt Deutschland. (2017). Pobrane 14.03.2017 z https://www.destatis.de.

Strachota, K. (2015). Bliski wschód w cieniu Państwa Islamskiego. Warszawa: OSW.

Szubart, K. (2015). RFN wobec kryzysu migracyjnego. Biuletyn Opinie FAE, 14. Pobrane 12.03.2017 z http://fae.pl.

TV2. (2015). Pobrane 16.05.2017 z http://nyheder. tv2.dk.

Wilk, W. (2016). Wojna w Syrii i kryzys humanitarny. Warszawa: Polskie Centrum Pomocy Międzynarodowej.

World Bank. (2017). Pobrane 11.03.2017 http:// data.worldbank.org.

wSensie.pl. (2016). Pobrane 16.05.2017 z http:// www.wsensie.pl.

Zeit. (2016). Knapp zwei Millionen Zuwanderer in 2015. Pobrane 13.03.2017 z http://www.zeit.de.

Informacje uzupełniające

Wkład autorski: autor zaakceptował ostateczną wersję artykułu.

Uwagi: wyniki badania były zaprezentowane w innej formie, tj. wystąpienia na VII Ogólnopolskiej Konferencji Naukowej Problemy gospodarki światowej (Torun, 28.04.2017). 
Aneks

Tabela 1.

Wysokość zasiłku Hartz IV w latach 2011-2016 (w EUR)

\begin{tabular}{ccccccc}
\hline Status rodzinny & 2011 & 2012 & 2013 & 2014 & 2015 & 2016 \\
\hline osoby samotne & 364 & 374 & 382 & 391 & 399 & 404 \\
osoby dorosłe prowadzące wspólne gospodarstwo domowe & 328 & 337 & 345 & 353 & 360 & 364 \\
dodatkowe osoby w rodzinie & 291 & 299 & 287 & 313 & 320 & 324 \\
dzieci od 15 do 18 roku życia & 287 & 287 & 289 & 296 & 302 & 306 \\
dzieci od 7 do 14 roku życia & 251 & 251 & 255 & 261 & 267 & 270 \\
dzieci poniżej 6 roku życia & 215 & 219 & 224 & 229 & 234 & 237 \\
\hline
\end{tabular}

Źródło: Opracowanie własne na podstawie Dojczlandinfo (2017).

Tabela 2.

Liczba wniosków o azyl złożonych w wybranych państwach UE w latach 2011-2016

\begin{tabular}{crrrrrr}
\hline Państwo & \multicolumn{1}{c}{2011} & \multicolumn{1}{c}{2012} & 2013 & 2014 & \multicolumn{1}{c}{2015} & \multicolumn{1}{c}{2016} \\
\hline UE & 309040 & 335290 & 431090 & 626960 & 1322825 & 1259955 \\
Niemcy & 53235 & 77485 & 126705 & 202645 & 476510 & 745155 \\
Szwecja & 29650 & 43855 & 54270 & 81180 & 162450 & 28790 \\
Włochy & 40315 & 17335 & 26620 & 64625 & 83540 & 122960 \\
Francja & 57330 & 61440 & 66265 & 64310 & 76165 & 84270 \\
Węgry & 1690 & 2155 & 18895 & 42775 & 177135 & 29430 \\
\hline
\end{tabular}

Źródło: Opracowanie własne na podstawie danych Eurostat (2017).

Wykres 1.

Saldo migracji w Niemczech w latach 2011-2015 (w liczbie osób)

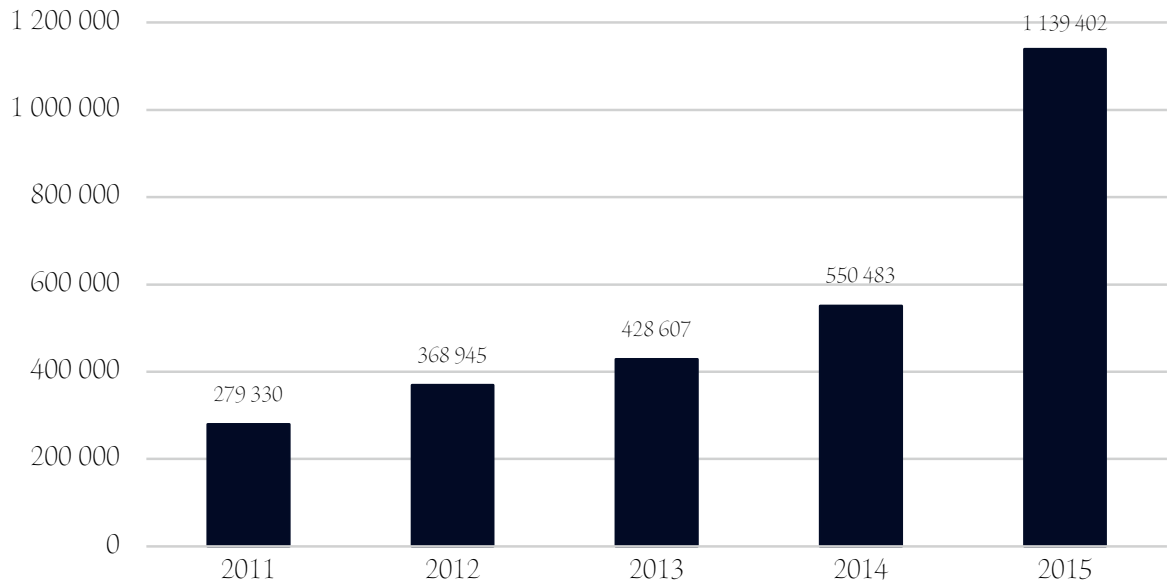

Uwagi:

Ze względu na brak danych pominięto 2016 rok.

Źródło: Opracowanie własne na podstawie danych Statistisches Bundesamt Deutschland (2017). 
Wykres 2.

Udział liczby wniosków o azyl złożonych w Niemczech w całkowitej liczbie wniosków o azyl złożonych na terytorium UE w latach 2011-2016 (w \%)

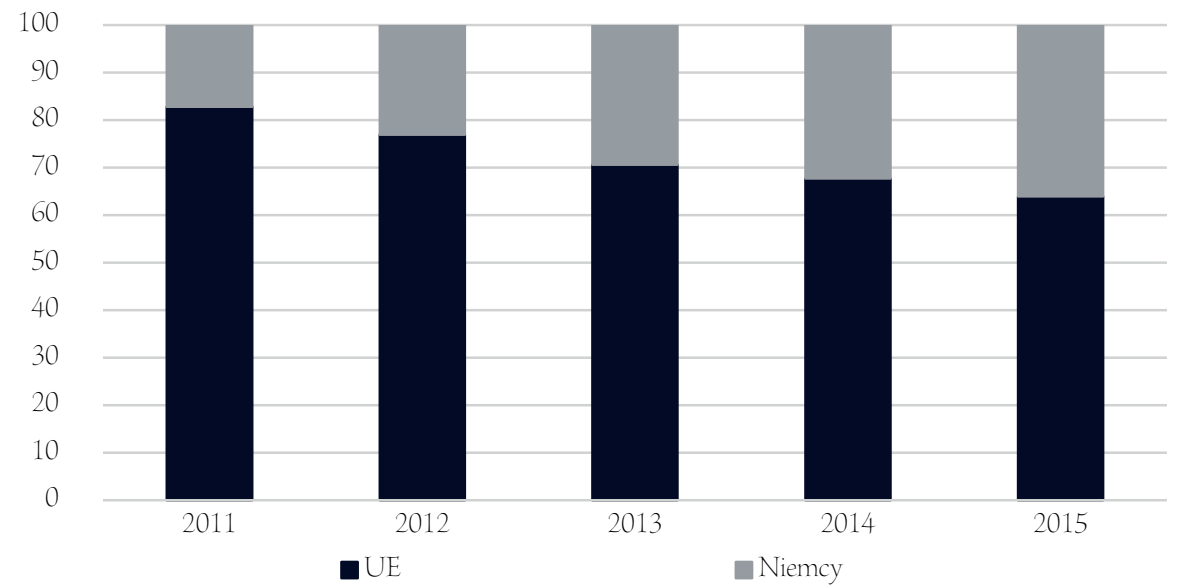

Źródło: Opracowanie własne na podstawie danych Eurostat (2017).

Wykres 3.

Liczba wniosków o azyl złożonych w Danii, Niemczech i Szwecji w latach 2011-2016 w stosunku do ogółu mieszkańców tych państw (w\%)

4,5

4,0

3,5

3,0

2,5

2,0

1,5

1,0

1,0

0,5

0,0

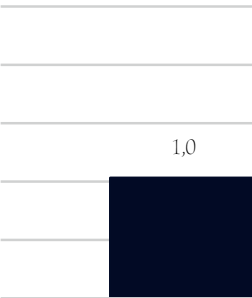

Dania
2,1

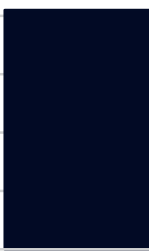

Niemcy
4,1

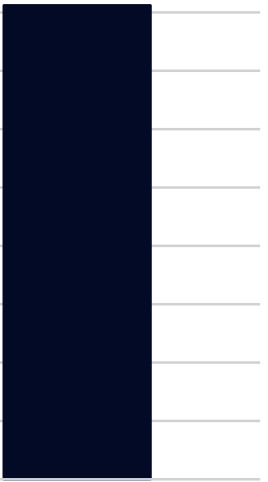

Szwecja

Źródło: Opracowanie własne na podstawie danych Eurostat (2017). 


\section{Relationship between German social policy and migration crisis}

\section{Abstract}

Motivation: The European migration crisis is currently one of Europés major socio-political problems. The civil wars, which began in Syria and Libya in 2011, caused an influx of migrants to Europe. This situation intensified especially in 2015, forcing European governments to create living conditions for arriving refugees. Ultimately, a very large part of immigrants arrived to the Federal Republic of Germany. The main motivation for choosing the subject of this article was to show one of the reasons for selecting exactly this direction of migration.

Aim: The aim of the article was to analyse the relationship between German social policy and the emergence of a migration crisis in that country. The study was conducted using an evaluation of quantitative measures. The analysis was based on the Eurostat and the German Federal Statistical Office data on applications for asylum and migration flows, as well as the law of the Deutscher Bundestag concerning social benefits for refugees.

Results: The analysis showed the relationship between the German government's social policy and the influx of immigrants to that country. Substantial social benefits for refugees were one of the main factors attracting migrants.

Keywords: migration crisis; social policy; Germany

JEL: 100; EOO; FOO 
